\title{
RECOVERING THE LIQUIDATOR'S COSTS ON THE WINDING UP OF A CORPORATE TRUSTEE
}

\author{
Victoria Stace $^{*}$
}

High Court decisions in New Zealand have identified three possible legal bases that might allow a liquidator to pay its costs out of the trust assets, on the liquidation of an assetless company that acted as trustee of a trading trust. This article suggests that there are problems with each of the bases identified, and that legislative amendment is required to ensure that the liquidator's authority to have access to trust assets to pay for the costs of liquidation in these circumstances is clearly established.

\section{INTRODUCTION}

Trading trusts are a reasonably common vehicle through which to operate a small business in New Zealand. ${ }^{1}$ Broadly defined, a trading trust is a trust that actively carries on a business. ${ }^{2}$ The trustee will commonly be a company, with no or limited assets of its own. In the leading case of Levin v Ikua, Heath J noted that the term "trading trust" was coined in Australia after the emergence of these entities in the 1970s to refer to "a business operated by an assetless company, in the capacity as a trustee for named beneficiaries". ${ }^{3}$ As a commercial vehicle, a trading trust combines the advantages of a

* LLB (Hons) Victoria University of Wellington, LLM (Cambridge), Senior Lecturer in Law at Victoria University of Wellington.

1 The Law Commission in its Review of the Law of Trusts Fifth Issues Paper, released in 2011, stated that "[t]rust structures have become increasingly popular for commercial purposes": Law Commission Court Jurisdiction, Trading Trusts and Other Issues: Review of the Law of Trusts Fifth Issues Paper (NZLC IP28, 2011) at [6.3]. It is difficult to ascertain empirically the incidence of trading trusts at present in New Zealand, as the status of the company as a trustee is not required to be disclosed through the Companies Register. However, a review of reported cases in New Zealand reveals that in at least 30 cases since 2010, a person referred to in the judgment was operating a business through an entity that was or could be described as a trading trust. These cases are listed in a schedule at the end of this article.

2 A trading trust can on this basis be distinguished from an investment trust under which property is held for investment: see Andrew Butler (ed) Equity and Trusts in New Zealand (2nd ed, Thomson Reuters, Wellington, 2009) at [16.1].

3 Levin v Ikua [2010] 1 NZLR 400 (HC) at [97]. 
company, namely limited liability and separate corporate personality, with the advantages of a trust, for example, relative privacy and anonymity. ${ }^{4}$ The trust does not have separate legal personality, so creditors contract with the company that is the trustee, and accordingly, it is the company that is liable for trust debts, including debts incurred in conducting the business carried on by the company as trustee $^{5}$

Complex issues arise if a trading trust becomes insolvent. If the trustee is an assetless company, then insolvency in this context means the trust does not have enough assets for the trustee to pay the trust debts. What can happen is that a liquidator may be appointed, to act as liquidator of the trustee, and such appointment will usually be by the court under s 241 of the Companies Act 1993.

All the debts incurred by the trustee in carrying out the trusts (including carrying on the business of the trust) are personal debts of the trustee. However, in the case of an assetless trustee, the only asset the trustee owns itself will be the right of indemnification from the trust assets for debts properly incurred in carrying out the affairs and business of the trust. This is what the liquidator must access, through its control of the company in liquidation, to pay the creditors of the trust. This is also the only source of money to pay the costs (comprising fees and expenses) incurred by the liquidator in the course of the liquidation.

In Levin v Ikua, Heath $\mathrm{J}$ took the opportunity to set out the law in New Zealand that applies on the winding up of a trading trust. In essence, the liquidator of an assetless trustee of a trading trust becomes the person responsible for controlling the company and, in that role, is able to exercise the right of indemnity that the company had, and thereby use trust assets to pay trust creditors. ${ }^{6}$

Heath J's comments have become the legal authority in New Zealand on the subject of the liquidator's role and powers in relation to the liquidation of a trustee of a trading trust. However, the facts of that case did not give the Court reason to consider the specific issue of whether, and on what basis, the liquidator has access to trust assets to pay the costs of the liquidation. A fundamental issue that arises from trust law when considering how the liquidator gets paid is that the trustee's right of indemnification relates to liabilities incurred in the course of properly carrying out the trusts or (more relevantly in this context) the business of the trust. The liquidator is not carrying out the business of the trust in the usual sense, or even the more general affairs of the trust, but is winding up the trustee.

4 Review of the Law of Trusts Fifth Issues Paper, above n 1, at 69. Heath J noted other advantages in Levin v Ikua, above n 3, at [102].

5 Review of the Law of Trusts Fifth Issues Paper, above n 1, at 67.

6 Levin v Ikua, above n 3, at [114]-[127]. Heath J did not say that the right of indemnification passes to the liquidator and in that regard his analysis appears to differ from the analysis made by the King CJ in the leading Australian case of Re Suco Gold Pty Ltd (1983) 7 ACLR 873 (SASC). King CJ stated (at 877): "[i]t is clear from the Octavo case that the trustee company's right of indemnity is a right of property which passes to the liquidator." 
The issue of how the liquidator's cost gets paid in this situation has been addressed in Australian cases. The Australian courts have taken the following, sometimes conflicting, views.

In Re Bryne Australia Pty Ltd in 1981, Needham J in the New South Wales Supreme Court (Equity Division) found that the liquidator is not a trust creditor, and that therefore the regime in the relevant Companies Act that gave the liquidator priority payment rights did not apply to trust assets. ${ }^{7}$

In Re Enhill Pty Ltd in 1983, the Full Court of the Victorian Supreme Court found that the proceeds of trust property are distributable amongst all creditors (including non-trust creditors such as the liquidator) on the basis that the trustee's right of indemnity is property of the company. ${ }^{8}$

In Re Suco Gold Pty Ltd in 1982, the Full Court of the Supreme Court of South Australia found that trust property can only be used to pay trust creditors, but if the trustee has already paid a particular debt and proceeds of trust assets are used to reimburse the trustee (this is called the trustee's right of recoupment), then those proceeds in the estate of the trustee are available for distribution to general creditors. ${ }^{9}$ This does not apply if the trust assets are being paid to the trustee to relieve a liability not yet discharged (this is called the trustee's right of exoneration). This is more likely to be the situation with an assetless trustee. Nevertheless, the liquidator is able to be paid out of trust assets because the relevant Companies Act could be construed as authorising this. The reasoning of the Court in Re Suco Gold is discussed more fully later in this article.

Recent Australian decisions have focused on the issue of whether the statutory priority regime applies to payment of the proceeds of trust assets to trust creditors. ${ }^{10}$ This issue has not received much attention by New Zealand courts. In Ranolf Co Ltd (in liq) v Bhana, the High Court stated in 2017 that the statutory priority regime does apply, but the Court gave no reasoning to support this assertion. ${ }^{11}$

The more fundamental issue is what is the conceptual basis on which the costs of the liquidation of an assetless (or near assetless) trustee may be paid (and more specifically how the trust assets are

7 Re Byrne Australia Pty Ltd [No 2] [1981] 2 NSWLR 364 (NSWSC).

$8 \quad$ Re Enhill Pty Ltd [1983] 1 VR 561 (VSC)

9 Re Suco Gold, above n 6.

10 See Re Amerind Pty Ltd (recs and mgrs apptd) (in liq) [2017] VSC 127, (2017) 320 FLR 118; Commonwealth $v$ Byrnes (in their capacity as joint and several recs and mgrs of Amerind Pty Ltd (recs and mgrs apptd) (in liq) [2018] VSCA 41, (2018) 54 VR 230; and Jones (liquidator) v Matrix Partners Pty Ltd, re Killarnee Civil \& Concrete Contractors Pty Ltd (in liq) [2018] FCAFC 40, (2018) 124 ACSR 568. For discussion of these cases see Christopher Symes and Beth Nosworthy "Paying the liquidators when the company is an insolvent trustee" (2018) 33 Aust Jnl of Corp Law 111; and Mark Leeming "Trustees' Rights of Indemnity, Insolvency and Statutory Distributions to Preferred Creditors" (2018) 92 ALJ 503.

11 Ranolf Co Ltd (in liq) v Bhana [2017] NZHC 1183 at [35]-[36]. 
accessed under the indemnity to pay the liquidator). This issue has only been directly considered by New Zealand courts on a few occasions since 2010, and only at High Court level.

The bases that have been identified for authorising payment of the liquidator's costs in the New Zealand cases are:

- the court's inherent jurisdiction (see for example, Finnigan v Yuan Fu Capital Markets Ltd); ${ }^{12}$

- $\quad$ the wording of the trustee's indemnity in the trust deed (see for example, Ranolf); or

- the legislative scheme of the relevant Companies Act, drawing on the Australian case of Re Suco Gold ${ }^{13}$ (this basis was identified in Ranolf but not relied on).

In Finnigan, the High Court found that the liquidators of a company that held investors' funds on trust had a right to be paid their costs out of the assets held on trust, stating that "[t]he court will order payment of remuneration out of trust assets independently of any agreement or of any power under the Companies Act, but in its inherent jurisdiction."14

In Ranolf, the High Court found that the right of indemnification in the relevant trust deed was broad enough to extend to all costs incurred (including by the liquidators) in enforcing the indemnity to enable trust creditors to be paid. ${ }^{15}$ The Court also referred to Re Suco Gold, where the Supreme Court of South Australia had found that by a combination of trustees' duties (to incur debts for the purposes of the trust business) and the scheme of the relevant Australian Companies Act (to pay the expenses of the winding up), the costs of the liquidation are expenses of the company and are therefore covered by the trustee's right of indemnity (whether arising by law or under the trust deed). However, the High Court in Ranolf did not rely on that Australian authority, preferring to base its decision on the wording of the indemnity in the trust deed.

In the recent case of NZ Natural Therapy Ltd $v$ Little, the High Court said simply that the company in liquidation: ${ }^{16}$

... was the legal owner of the assets of the Trust and could access those assets, by way of indemnity, for

liabilities incurred as trustee. The Company had no function other than being trustee for the Trust.

Therefore, the costs of its liquidation are liabilities incurred as trustee of the Trust.

It is suggested that this pragmatic approach can be challenged in its assertion that that costs of liquidation are to be treated as just another debt of the company (as explained below). It also lacks

12 Finnigan v Yuan Fu Capital Markets Ltd (in liq) [2013] NZHC 2899.

13 Re Suco Gold, above n 6.

14 Finnigan, above n 12, at [70(a)]. The term "remuneration" included fees and expenses.

15 Ranolf, above n 11, at [33]-[34].

16 NZ Natural Therapy Ltd (in liq) v Little [2018] NZHC 2164 at [7]. 
analysis of the issue of whether the connection between the activities of the liquidator and the affairs of the trust is sufficiently close to come within the scope of the indemnity.

No clear consensus has emerged from the New Zealand cases on the correct legal basis on which a liquidator of a trustee of a trading trust can access the trust assets to pay the costs of liquidation. Liquidators must be able to have access to some assets to pay the costs of liquidation. Otherwise it would not be possible to find a liquidator to act in this situation, and liquidation is a necessary and recognised phase of any corporate entity's existence. The general sense that there "must be a way" to pay the liquidator of an assetless trustee out of the trust assets emerges from the judgments and likely underlies the decisions reached. This article considers each of the legal bases that have been identified in the New Zealand cases. It concludes that none appears to provide an entirely satisfactory basis for payment of the liquidator's costs. It suggests the answer lies in amending the Companies Act 1993 to provide that the liquidator of a corporate trustee can take its costs out of trust assets in certain circumstances.

\section{FIRST POSSIBLE BASIS: THE COURT'S INHERENT JURISDICTION}

The court has an inherent jurisdiction to allow a liquidator to pay itself its costs incurred in relation to investigation and realisation of trust assets, but only where those actions are carried out for the benefit of the beneficiaries of the trust. ${ }^{17}$ This inherent jurisdiction does not extend to paying the liquidator's general costs associated with the liquidation of the trustee.

McGechan J described how what is sometimes known as the Re Berkeley Applegate principle ${ }^{18}$ applies in New Zealand, ${ }^{19}$ in Re Newsmakers International Ltd (in liq), stating: ${ }^{20}$

... when a liquidator is forced to carry out work in relation to assets held on trust, for the benefit of the beneficiaries concerned, the Court has an inherent jurisdiction to allow reasonable costs against those assets.

17 Re Berkeley Applegate (Investment Consultants) Ltd [1989] Ch 32 (Ch). Followed in New Zealand in Re Newsmakers International Ltd (in liq) HC Napier M153/86, 24 February 1994 at 6; and Hollis v Total Debt Solutions (2009) Ltd (in liq) [2017] NZHC 1383 at [11] and [12].

18 Re Berkeley Applegate, above n 17.

19 See for example Gillan v HEC Enterprises Ltd [2016] EWHC 3179 (Ch), [2017] 1 BCLC 340 at [5]. See also Lynton Tucker, Nicholas Le Poidevin and James Brightwell Lewin on Trusts (19th ed, Sweet \& Maxwell, London, 2014) at [20-240], [20-246] and [22-023].

20 Re Newsmakers International, above n 17, at 6. See also Re National Pacific Securities Ltd (in rec and liq) (1991) 5 NZCLC 67,332 (HC). 
The underlying principle is that "[h]e who saves trust assets for the benefit of beneficiaries, properly can ask those beneficiaries to meet his proper expenses." 21 This does not however extend to the general expenses of a winding up: "the activity concerned must relate to trust assets in direct fashion". ${ }^{22}$

Before Re Berkeley Applegate (Investment Consultants) Ltd clarified this principle, ${ }^{23}$ on two occasions the New Zealand High Court had to grapple with the issue of how to allow a liquidator's costs to be paid out of trust assets. The conceptual analysis is at times confusing in these decisions and both decisions show the court taking a pragmatic approach, that "of course" the liquidator must somehow have access to trust assets to pay its reasonably incurred costs. There was a consistent theme that in order to rely on the court's inherent jurisdiction, the liquidator's actions must directly relate to dealing with the assets for the benefit of the beneficiaries. Those two cases are Re Secureland Mortgage Investments Ltd (in liq) No $2^{24}$ and Re Francis James Nominees (in liq). ${ }^{25}$

Re Secureland related to a contributory mortgage arrangement. Investors paid over their money and were promised interest at a certain rate. All investments received were pooled and lent out on security of mortgages over land. The investment company, Secureland Mortgage Investments Ltd (Secureland), held the investments on behalf of investors. There was no contractual right for Secureland to charge fees (its return was the excess received from the mortgagors over the agreed interest paid to investors).

The Court found that there was a statutory and inherent power to allow payment to the trustee of costs the trustee had incurred (covering both fees and expenses), by way of indemnification out of trust assets (this was necessary to overcome the fact that the trust deed did not allow any charges to be levied against the investors' funds). The trustee's right to indemnification did not pass to the liquidator. ${ }^{26}$ However, because "[t]he Provisional Liquidator ... had to take extraordinary steps to protect the trust property for the benefit of the investors or beneficiaries," it was "appropriate that he should be reasonably remunerated for his services". ${ }^{27}$ It was also relevant that "[t]here [was] no adequate source from which he may be properly remunerated except the trust property." 28 The Court decided to exercise its inherent jurisdiction to allow the trustee to access trust assets to pay

21 At 6 .

22 At 6 .

23 Re Berkeley Applegate, above n 17.

24 Re Secureland Mortgage Investments Ltd (in liq) No 2 (1988) 4 NZCLC 64,266 (HC).

25 Re Francis James Nominees Ltd (in liq) (1988) 4 NZCLC 64,279 (HC).

26 Re Secureland Mortgage Investments, above n 24, at 64,276.

27 At 64,276 .

28 At 64,276 
remuneration and expenses. ${ }^{29}$ How that right was applied to pay the liquidator is not clear from the judgement. The right may have been vested in the liquidator by the Court. ${ }^{30}$

This decision does not provide clear principles on the issue of how a liquidator can access trust assets to pay its costs and fails to clearly distinguish between the legal basis for payment of the trustee's costs and the legal basis for payment of the liquidator's costs. What is clear from this decision is that the Court exercised its inherent jurisdiction only because the liquidator took steps to protect the trust property for the benefit of the beneficiaries. It is also clear that the liquidator was only able to access the trust assets for costs incurred (remuneration and expenses) to the extent it was acting in relation to administering the trusts and not as liquidator more generally. ${ }^{31}$

Re Francis James Nominees concerned a company in liquidation (FJN) that had acted as nominee to hold investments made by investors. The main business was conducted by one or more partnerships that carried out business as mortgage brokers. Individuals invested in mortgages arranged by the partnerships, with the investments being held in the name of FJN. There were no trade creditors of FJN. The only people interested in the investments held by FJN were the investors who were considered to be beneficiaries of trusts of which FJN was the trustee.

The liquidator recovered around $\$ 600,000$ and it was possible to ascertain which investors these funds were beneficially owned by. The liquidator argued that the Companies Act 1955 authorised all expenses properly incurred in the winding up to be payable out of the "assets of the company" and that the word "assets" included assets held on trust. The Court identified two possible conceptual grounds on which the liquidator, who had acted properly in taking the steps he did, might be able to access the assets held on trust to pay its costs.

The first was the wording of the Companies legislation, giving a broad interpretation to what were the "assets" of the company, and drawing on a series of Australian cases (including Re Suco Gold) which grappled with this issue. The law arising from these cases was summarised by Justice Doogue in Re Francis James as "in one way or another the Liquidator was to be entitled to some remuneration for bringing in the trust assets". ${ }^{32}$

29 At 64,276

30 The Court stated that the liquidator "should be fully and fairly remunerated to date as trustee for his actions on behalf of the beneficiaries" suggesting that the liquidator acquired the trustee's right to access trust assets (at 64,277). Interestingly, the Court also stated that no breaches of trust by the trustee affected the liquidator's claim (at 64,276). This finding is inconsistent with established law on the trustee's right of indemnification (discussed later in this article).

31 At 64,277 Holland $\mathrm{J}$ said "care must be taken to ensure that the remuneration is qua trustee and not remuneration qua Provisional Liquidator in respect of which his rights must be restricted".

32 Re Francis James Nominees, above n 25, at 64,283. 
The second ground identified was that the court had an "inherent jurisdiction to allow a trustee remuneration and indemnity from trust property", 33 citing Re Secureland Mortgage as authority.

Doogue $\mathrm{J}$ did not indicate which ground he considered applied in this case, saying: ${ }^{34}$

In my view, therefore, regardless in which way this case should conceptually be approached, the result must practically be the same and the Official Assignee should be entitled to recover remuneration in the sum already indicated from the trust assets held by him ...

The issue arose again in the context of the liquidation of a company that held investments under a contributory mortgage arrangement in Re Landbase Nominee Co Ltd in 1989.35 The company in liquidation solicited money from the public for lending on mortgage security. When addressing the issue of how the liquidator would be paid, the Court referred to Re Francis James as authority for the proposition that "in proper cases a liquidator who has realised trust assets is entitled to take his costs from those assets" based on the inherent jurisdiction of the court to "protect the position of the liquidator". 36

The next New Zealand case to consider this issue, Re Aramiru Holdings Ltd, related to the failed Equiticorp Group and involved an application by the statutory managers. The company in receivership had been trading as a share broker. ${ }^{37}$ The statutory managers asked the High Court if they could take their costs from the funds held by the company on behalf of clients. The Court based its decision on the United Kingdom authority of Re Berkeley Applegate (which the Court noted had not been available when Re Secureland and Re Francis James were decided). ${ }^{38}$ The principle established in Re Berkeley Applegate focuses on the beneficiaries' interest in trust property being made subject to the payment of costs incurred by a person acting in connection with that property. The principle was stated in $R e$ Aramiru Holdings in these terms (quoting from Re Berkeley Applegate): ${ }^{39}$

... where a person seeks to enforce a claim to an equitable interest in property, the court has a discretion to require as a condition of giving effect to that equitable interest that an allowance be made for costs incurred and for skill and labour expended in connection with the administration of the property.

33 At 64,284.

34 At $64,285-64,286$.

35 Re Landbase Nominee Co Ltd HC Auckland M1258/88, 4 May 1989.

36 At 24

37 Re Aramiru Holdings Ltd [1989] 3 NZLR 487 (HC). Followed in McKenzie v Alexander Associates Ltd (No 1) (1991) 5 NZCLC 67,030 (HC).

38 Re Aramiru Holdings, above n 37, at 505.

39 At 504, quoting Re Berkeley Applegate, above n 17, at 50. 
The liquidator's costs must be "qua trustee" and directly linked to efforts in relation to the trust property. ${ }^{40}$ In the event that there was a deficiency in the assets beneficially owned by the company, then the court had an inherent jurisdiction to remunerate the liquidator "to the extent to which their services relate to the preservation and proper disposal [of the trust property] but not further". ${ }^{41}$

Re Newsmakers, a decision of the High Court in 1994, concerned the liquidation of a company in possession of certain property that turned out not to belong to the company. The liquidator sold the property after getting directions from the Court to do so. The liquidator ended up with a sum of around $\$ 8000$ (held on trust) and costs in excess of that amount. There were no creditors. Referring to $R e$ Secureland and Re Francis James as authority, the High Court stated: ${ }^{42}$

... when a liquidator is forced to carry out work in relation to assets held on trust, for the benefit of the beneficiaries concerned, the Court has an inherent jurisdiction to allow reasonable costs against those assets. There is an underlying and obvious equity. He who saves trust assets for the benefit of beneficiaries, properly can ask those beneficiaries to meet his proper expenses. It has been made clear that jurisdiction does not extend to general expenses of a winding up: the activity concerned must relate to trust assets in direct fashion.

The 2013 decision in Finnigan concerned a company that operated a trading platform, where investors placed money with the company and then were able to trade in certain types of securities. ${ }^{43}$ The company's return was by way of commission on the investments. On the date of liquidation it had assets comprising shares and money in bank accounts of around \$1 million. Investors were owed over $\$ 1$ million and there were also creditors of the company (for example, employees' wages).

The Court found that all funds the company received from investors were held on trust. This comprised almost all the assets of the company. ${ }^{44}$ The liquidators encountered numerous difficulties when investigating the affairs of the company. When considering the issue of how the liquidators' costs would be paid, the High Court said simply: ${ }^{45}$

The courts have recognised that liquidators and similar insolvency administrators required to deal with assets held on trust by the insolvent entity have a right to be paid out of the assets held on trust.

40 At 504 .

41 At 504 .

42 Re Newsmakers International, above n 17, at 6.

43 Finnigan, above $\mathrm{n} 12$.

44 There were some funds that the company held on its own account, which formed a pool of money out of which a proportion of liquidator's expenses could be paid and the non-trust creditors could be paid in part.

45 Finnigan, above n 12, at [70]. 
This power exists (said the Court) "independently of any agreement or of any power under the Companies Act, but in its inherent jurisdiction." ${ }^{46}$ The Court stated "[t]he right to remuneration is for work related to the trust assets, not to the conduct of the liquidation generally." 47

Finally, in Hollis v Total Debt Solutions (2009) Ltd (in liq), the issue arose in the context of the winding up of a debt collection company. ${ }^{48}$ All the funds held by the company at the date of liquidation were held on trust for other companies. The liquidators wanted to have recourse to those funds to pay their costs. The High Court applied the law established in Re Newsmakers to the effect that: ${ }^{49}$

[W]hen a liquidator is forced to carry out work in relation to assets held on trust, for the benefit of the beneficiaries concerned, the Court has an inherent jurisdiction to allow reasonable costs against those assets. ... the jurisdiction does not extend to general expenses of the winding up: the activity concerned must relate to trust assets in a direct fashion.

The main issue with relying on the court's inherent jurisdiction for payment of the liquidator's costs is that it only arises in relation to costs incurred by the liquidator's efforts that are directly related to preserving or realising the trust property for the benefit of the beneficiaries.

Given that the trust creditors have a right in equity to subrogate to the trustee's right of indemnity to get their debt paid out of trust assets whether or not there is a liquidator involved, ${ }^{50}$ it would seem that the persons who primarily benefit from the liquidator's actions of conducting the winding up (and as part of that, paying the trust creditors) are not in the usual case going to be the beneficiaries but are the trust creditors themselves, who are not only paid (to the extent that the trust assets are sufficient to meet trust liabilities) but also relieved of the task of seeking payment through subrogation. This suggests that the court's ability to use its inherent jurisdiction established by this line of cases is going to be limited.

\author{
46 At $[70(a)]$. \\ 47 At [70(d)]. \\ 48 Hollis v Total Debt Solutions, above n 17. \\ 49 At [11], citing Re Newsmakers International, above n 17, at 6. \\ 50 Butler, above $\mathrm{n} 2$, at [16.6.7].
}




\section{SECOND POSSIBLE BASIS: THE INDEMNITY IN THE TRUST DEED AUTHORISES THE PAYMENT OF THE LIQUIDATOR'S COSTS}

In Ranolf, the High Court relied on the wording of the indemnification in the relevant trust deed to find that the liquidator's costs could be paid out of trust assets. ${ }^{51}$ The relevant part of the clause in the trust deed stated: 52

The Trustees and their personal representatives and assigns and their estates and effects shall be kept safe harmless and indemnified against all actions liabilities claims damages costs and expenses in relation to or arising out of their Trusteeship ...

Gilbert J's reasoning was as follows: ${ }^{53}$

The words "in relation to or arising out of" are of wide import. In my view, they extend to cover the costs reasonably incurred by the trustee in enforcing the indemnity where this becomes necessary to meet Trust debts properly incurred by them. Those costs can fairly be said to "arise out of", or have been incurred "in respect of", the trusteeship. It follows that the indemnity covers not only the debts due to the Trust creditors but also all costs reasonably incurred in enforcing the indemnity to enable those debts to be paid.

Ranolf has been placed in liquidation. That was the likely consequence if it was not placed in sufficient funds to meet the legitimate claims of Trust creditors. The need to enforce the indemnity in such circumstances can only be carried out by the liquidators. Their costs must therefore be within the contemplation of the indemnity given to a trustee company known to have no capital or assets of its own.

Several issues arise out of this basis for payment of the liquidator's costs, including that:

(a) there may not be an indemnity in the trust deed;

(b) the right of indemnification may be impaired in some way so the liquidator is unable to access it;

(c) the right of indemnification may be excluded or limited by the trust deed; and

(d) (more fundamentally) the notion that the trustee's indemnity can authorise the payment of the liquidator's costs on a winding up is arguably misconceived because it fails to take into account that the right of indemnification only relates to trust debts, and the costs incurred by a liquidator are not a trust debt.

Each of these issues is elaborated on in the following paragraphs.

51 Including reasonable remuneration, notwithstanding that there was no express provision for remuneration in the trust deed.

52 Emphasis added.

53 Ranolf, above n 11, at [33]-[34]. 


\title{
A There May not be any Right of Indemnification in the Trust Deed
}

It is possible that the trust deed may not contain a clause giving the trustee a right of indemnification. In this situation the liquidator can look to the indemnity under the Trustee Act 1956 and/or the indemnity implied by common law. ${ }^{54}$ Both the Trustee Act and the common law grant the trustee an indemnity for expenses incurred in relation to the execution of the trusts (but not extending to remuneration, unless the court allows). ${ }^{55}$

Section 38(2) of the Trustee Act states: ${ }^{56}$

\begin{abstract}
A trustee may reimburse himself or pay or discharge out of the trust property all expenses reasonably incurred in or about the execution of the trusts or powers; but, except as provided in this Act or any other Act or as agreed by the persons beneficially interested under the trust, no trustee shall be allowed the costs of any professional services performed by him in the execution of the trusts or powers unless the contrary is expressly declared by the instrument creating the trust: provided that the court may on the application of the trustee allow such costs as in the circumstances seem just.
\end{abstract}

Section 38 has been rewritten in the Trusts Act 2019, following on from the Law Commission's recent review of the law of trusts. ${ }^{57}$ Under the s 81 of the Trusts Act, the wording of the statutory trustee's indemnity is as follows:

(1) A trustee is personally liable for an expense or a liability incurred by the trustee when acting as a trustee.

(2) However, a trustee who incurs an expense or a liability when acting reasonably on behalf of the trust is entitled,-

(a) if the trustee has paid the expense or discharged the liability out of the trustee's own funds, to reimbursement from the trust property; or

(b) in any other case, to pay the expense or discharge the liability directly from the trust property (or to have it paid or discharged by a remaining trustee).

(3) The operation and enforcement of the indemnity in this section is governed by the rules of the common law and equity relating to trusts.

(4) This section does not limit any indemnity available at common law or in equity.

54 Worrall v Harford (1802) 8 Ves 4, 32 ER 250 (Ch). See further Butler, above n 2, at [16.6.2].

55 The court can allow trustee remuneration under s 38(2) of the Trustee Act 1956 (and s 139 of the Trusts Act 2019). The court also has a power to allow a trustee a commission for services, under s 70 of the Trustee Act, and it also has an inherent jurisdiction to allow trustee remuneration - see Butler, above $\mathrm{n} 2$, at [16.6.12], $\mathrm{n}$ 212.

56 Emphasis added.

57 New Zealand Law Commission "Law of Trusts" <www.lawcom.govt.nz/our-projects〉. The Trusts Act will come into force on 30 January 2021. 
The absence of a right of indemnification in the trust deed will not therefore be fatal to a liquidator's claim. Applying a liberal interpretation to the wording in each of the statutory formulations of the indemnity it is possible to apply Gilbert J's reasoning to find the costs of the liquidator are covered. However it is suggested there are issues as to whether any of these rights of indemnification should properly be construed as extending to the costs incurred by a liquidator on a winding up (discussed below).

\section{$B$ The Right of Indemnification May be Impaired in Some Way so the Liquidator is Unable to Access it}

It is possible that the trustee's right of indemnification may be impaired. This can happen, for example, if the trustee did not have the power to enter into the liability that is sought to be indemnified, or if the trustee has breached a duty in entering into the liability. ${ }^{58}$ The indemnity can also be impaired by a breach of trust unrelated to the particular liability if, for example, the trustee has breached a duty owed to the beneficiaries that results in loss which can be set off against the amount owing to the trustee under the indemnity. ${ }^{59}$ If the right of indemnification is impaired, then not only are trust creditors unable to subrogate to the trustee's right of indemnification to recover their debt, the liquidator will also be unable to access it.

The Trusts Act addresses this concern in part in s 86, which provides that if the trustee's indemnity is impaired for some reason, for example a breach of trust, then in relation to a trust creditor that has acted in good faith and given value and where the trust has received a benefit from the transaction, the creditor has a claim against the trustee that may be satisfied by the creditor being indemnified from the trust property. However this cannot help the liquidator, as the liquidator cannot accurately be described as a "trust creditor". This is because the liquidator provides its services to the company in liquidation not as trustee but as a company in its own right. It is also questionable whether the liquidator can accurately be described as a "creditor" at all given that its costs are not regarded by the Companies Act as a debt (discussed further below).

\section{The Right of Indemnification Might be Excluded or Limited by the Trust Deed}

It is possible that the trust deed may purport to exclude the trustee's right of indemnification. The Law Commission has suggested in its review of the law of trusts that the trustee's right of indemnification cannot be excluded by the trust deed, but the law is unsettled on this point. ${ }^{60}$

58 See Butler, above n 2, at [16.6.8].

59 At [16.6.8].

60 Review of the Law of Trusts Fifth Issues Paper, above n 1, at 70. See also Butler, above n 2, at [16.6.11], where the text states that the better view is that the trustee's right of indemnity can be limited but not excluded entirely because it is an essential part of trusteeship. 


\section{$D$ The Right of Indemnification only Relates to Trust Debts, and does not Include the Liquidator's Costs Incurred on a Winding Up}

If one accepts that trust assets can only be used to meet trust liabilities, which it is suggested is a correct principle, having been firmly established by the Australian decisions starting with Re Suco Gold and also being supported by the leading text, ${ }^{61}$ then it is arguable that the trustee's indemnity (be it in the deed, the statute or at common law) does not extend to the costs of liquidation. The liquidator's costs do not directly arise out of execution of the trusts. They are only indirectly related to carrying on the trust business (being expenses incurred in the course of paying the trust creditors on liquidation). It must be at least arguable that what the liquidator is doing in winding up the trustee is too far removed from the type of expense to which the indemnity applies for it to be within the contemplation of the indemnity. In particular, it is suggested that the costs of liquidation are more properly to be regarded as a liability related to the affairs of the trustee in its capacity as a private company and not as a trustee, given that the liquidator is appointed to the company as a company and not as a trustee. It is acknowledged that there is a counterargument to this, that the liquidator's work does relate to exoneration of the trustee, by paying or facilitating the payment of the trust creditors, and that therefore there is a sufficient (or at least some) connection. This is how Gilbert $\mathbf{J}$ was able to utilise the indemnity in the Ranolf trust deed (but noting that it may have been important in Ranolf that that indemnity was given to a company known to have no assets of its own).

\section{THIRD POSSIBLE BASIS: PAYMENT TO THE LIQUIDATOR IS AUTHORISED BY THE SCHEME OF THE COMPANIES $A C T$}

Essentially this approach, which finds strongest authority in the Australian case of Re Suco Gold, is that the law in the Companies legislation around liquidations, and in particular payment of liquidators' costs, must implicitly authorise the payment of the liquidator's costs out of the trust assets, in the situation of an assetless trustee whose only role is to act as the trustee of the trust (or potentially more than one trust) and which only has trust-related debts, because there is no other source of money. The approach has intrinsic appeal. However, it requires a broad and purposive interpretation of the relevant Companies legislation provisions. There are some differences in the language used in the New Zealand Companies Act (by comparison to the Australian legislation considered in Re Suco Gold) that may mean the reasoning in Re Suco Gold could not be directly applied. This basis may also have limited application and only be available in the situation that occurred in Re Suco Gold, namely an assetless trustee with only trust creditors. ${ }^{62}$

61 See Butler, above n 2, at [16.6.12], where the text states "[t]rust assets cannot be used to satisfy the trustee's private liabilities".

62 If there were non-trust creditors the liquidator's expenses could not be said to be all related to the affairs of the trust. 
In Re Suco Gold, the Supreme Court of South Australia had to consider a liquidator's request for directions to apply money resulting from the liquidation of a company that acted as trustee, in payment of the liquidator's costs incurred in winding up the company. The company was the trustee of two unit trusts. It had no assets apart from the right of indemnity contained in the trust deeds (there was also a statutory right of indemnity under the relevant Trustee Act). Its only debts related to carrying out the trusts. There were insufficient trust assets to meet those liabilities. Previous Australian authority had conflicted over whether the liquidator had to be a "trust creditor" or not in order to get paid out of trust assets. ${ }^{63}$ The Court in Re Suco Gold found that the right of indemnity could not be used to meet liabilities to non-trust creditors. However, that did not preclude payment of the liquidator's costs in this case, out of the trust assets. ${ }^{64}$

King CJ noted the practical consideration that "[u]nless that course can be followed [i.e. payment of the liquidator's costs out of trust property], the liquidation of a trustee company without assets of its own cannot proceed. ${ }^{65}$ The reasoning he then applied to allow this to happen was as follows: ${ }^{66}$

- it is part of the duty of the trustee to incur debts for the purposes of the trust businesses and, of course, to pay those debts;

- $\quad$ upon winding up the trustee (being a company), those debts can only be paid in accordance with the provisions of the relevant Companies Act. This requires necessarily that there be a liquidator and that he or she incur costs and expenses and be paid remuneration;

- $\quad$ section 292 of the Companies Act 1962 (SA) provided that there be paid the costs and expenses of winding up, the taxed costs of the petitioner and the remuneration of the liquidator "in priority to other unsecured debts". The expression "other unsecured debts" appeared to imply that the costs and expenses of winding up, the petitioner's costs and the liquidator's remuneration are regarded by the statute as debts of the company; and

63 In Re Byrne Australia Pty Ltd (No 2) [1982] 2 NSWLR 364 (NSWSC), Needham J held that the liquidator was not a trust creditor and that his costs and expenses therefore could not be paid out of the trust fund. The Court in Re Enhill Pty Ltd [1983] 1 VR 56 (VSCA) found that the trustee company's right of indemnity forms part of the assets of the company in a winding up and is property under the control of the liquidator. The Court considered that that proposition led to the conclusion that the trust assets were divisible among the company's creditors generally and not merely among the trust creditors and that those assets were available to meet the liquidator's costs and expenses by virtue of s 292 of the Companies Act 1961 (Vic).

64 The directions which the court ultimately gave were made on the assumption that there were on foot valid rights of indemnity against the property of the trusts. In other words, if the trustee had breached the trust and lost the right of indemnity then there would have been no basis on which the liquidator could use it.

65 Re Suco Gold, above n 6, at 883.

66 At 883. King CJ added that if he was wrong, then he would "like Lush J in Re Enhill Pty Ltd, be prepared to rely on the principle enunciated by Dixon J in Re Universal Distributing Co Ltd (1933) 48 CLR 171 at 174 $5 "$. The principle established by Dixon $\mathrm{J}$ was that a liquidator who incurs costs in preserving and realising secured property can take the costs of doing so before paying the secured creditor, even if that work had to be done in order to realise assets for the unsecured creditors. 
- as the company's obligation as trustee to pay the debts incurred in carrying out the trust cannot be performed unless the liquidation proceeds, it was reasonable to regard the expenses mentioned above as debts of the company incurred in discharging the duties imposed by the trust and as covered by the trustee's right of indemnity.

Jacobs J agreed, stating: ${ }^{67}$

The liquidator is appointed by the Court, and is answerable to the Court, and is clearly entitled to remuneration for his services whether fixed by the Court or by the creditors whose proofs have been admitted. He would not be available to act at all unless the Act is allowed to speak according to its tenor; and indeed, unless the Act so speaks, the Court itself would be in no better position to recover the costs and expenses of the winding up, if the winding up were undertaken by the Court without the intervention of a liquidator. I cannot think that the legislature intended such a result, and I am not persuaded that the language of the Act, or the general law, compels such a result.

In Jones (liquidator) v Matrix Partners Pty Ltd, re Killarnee Civil \& Concrete Contractors Pty Ltd (in liq), a decision of the Federal Court of Australia in 2018, Allsop CJ supported the approach taken in Re Suco Gold, stating "[i]f I may respectfully say so, there is not only practical wisdom in this approach, but also a sufficient grounding in the terms of the statute. "68

Re Suco Gold was referred to with approval in Re Secureland, where Holland J said he found King CJ's decision "particularly helpful" and was content to "adopt his reasoning" in concluding that the liquidator "acquired on the winding up the right of the company as trustee to retain trust assets in his hands until his expenses and remuneration as trustee were paid". ${ }^{69}$ However, Holland J based his decision on the court's inherent jurisdiction as there was no right in the trust deed to charge for fees or recoup expenses from trust property. Re Suco Gold was also referred to in Re Francis James, but not applied, as here also the Court based its decision on the inherent jurisdiction basis. ${ }^{70}$

In Ranolf, the High Court stated that Re Suco Gold had been applied in New Zealand in several cases, namely Re Secureland Mortgage, Re Francis James and one other, Official Assignee in Bankruptcy of the Property of Perkins $v$ Smith. ${ }^{71}$ However, none of those cases applied the principles

67 Re Suco Gold, above n 6, at 886.

68 Jones (liquidator) v Matrix Partners Pty Ltd, re Killarnee Civil \& Concrete Contractors Pty Ltd (in liq) [2018] FCAFC 40, (2018) 354 ALR 436 at [106].

69 Re Secureland Mortgage Investments, above n 24, at 64,275.

70 Re Francis James Nominees, above n 25, at 64,283. Doogue J said (at 64,286):

I am satisfied that it is appropriate that the inherent jurisdiction of the Court be exercised to protect the position of the Official Assignee in respect of the trust funds that have been obtained by him for the benefit of the beneficiaries under those trusts.

71 Official Assignee in Bankruptcy of the Property of Perkins $v$ Smith [2013] NZHC 3217 did not address the issue of how to recover a liquidator's costs from the assets of a trust. In a recent decision of the High Court 
set out in Re Suco Gold noted above. In Ranolf, the court had to address the issue of whether the costs of a liquidator of an assetless trustee of a trading trust could be paid out of trust assets. The liquidator argued that Re Suco Gold provided the authority for doing so but the Court based its decision on the wording of the indemnity in the trust deed. ${ }^{72}$

There are potential issues with applying what can be described as the "legislative scheme" approach in New Zealand due to the differences in wording in the New Zealand Companies Act as compared with the relevant Australian legislation, which was the (then applicable) Companies Act. King CJ focused on the wording of s 292 and the use of the word "debts", saying: ${ }^{73}$

The expression "other unsecured debts" appears to imply that the costs and expenses of winding up, the petitioner's costs and the liquidator's remuneration are regarded by the statute as debts of the company. ...

it seems to me to be reasonable to regard the expenses mentioned above as debts of the company incurred in discharging the duties imposed by the trust and as covered by the trustee's right of indemnity.

By contrast, in the New Zealand Companies Act 1993, the liquidator's costs and expenses are not referred to as "debts" but as "claims" that are payable out of the assets of the company. This creates a hurdle to establishing that the liquidator's costs are to be regarded in the same category as trust creditor debts.

Under the New Zealand Companies Act, a liquidator is entitled to charge reasonable remuneration (s 276) (and court-appointed liquidators are subject to regulations that set prescribed rates) and the expenses and remuneration of the liquidator are payable out of the assets of the company (s 278). Under s 312(1):

The liquidator must pay out of the assets of the company the expenses, fees, and claims set out in Schedule 7 to the extent and in the order of priority specified in that schedule and that schedule applies to the payment of those expenses, fees, and claims according to its tenor.

(Camray Farms Ltd (in liq) v BL (Nature Sunshine) Trustee Ltd [2019] NZHC 2536) Edwards J, echoing Ranolf stated that that Re Suco Gold had been followed in Re Secureland Mortgage and Re Francis James, then stated that the recovery by the liquidator of its fees and costs is not pursuant to the order of priorities in the Companies Act but "according to the rules of equity that apply when a trust is wound up" (at [71]). The liquidator's costs were considered to be a debt incurred in performing the duties of the trustee. However there was only brief analysis of the issue.

72 Ranolf, above n 11, at [32]-[36].

73 Re Suco Gold, above n 6, at 883. 
Under sch 7, the first preferential claim is "fees and expenses properly incurred by the liquidator in carrying out the duties and exercising the powers of the liquidator, and the remuneration of the liquidator." 74 These are referred to as "claims" in the schedule. ${ }^{75}$

The role of the liquidator in relation to the company is a unique one, which may be described as principally agent for the company, who occupies a position that is in some respects fiduciary, but who is bound by the statutory duties imposed by the Companies Act, and, in the case of a liquidator appointed by the court, who is also an officer of the court. ${ }^{76}$ The costs incurred by the liquidator in carrying out its role are payable to the liquidator under the authority of the Companies Act. But those costs are not a debt of the company in the usual sense. They cannot therefore be regarded (to use King CJ's words) as "debts of the company incurred in discharging the duties imposed by the trust". ${ }^{77}$

\section{LEGISLATIVE CLARIFICATION IS DESIRABLE}

Legislation is desirable to clarify that a liquidator of a company that acts as a trustee is able to exercise the trustee's right of indemnification to pay, from trust assets, its reasonably incurred costs (including remuneration and expenses) that relate to the winding up of the company, to the extent that those costs relate to investigations and realisations of assets for trust creditors. Given that the liquidator's right to claim remuneration and expenses from the company stems from the Companies Act, it would seem appropriate to include in that Act a provision stating how those costs are to be paid in the event the company is or has been a trustee. Such a provision should allow for apportionment in the event that the company is the trustee of more than one trust, or if the company holds assets in its own right in addition to the trust assets. Legislation could also clarify that the liquidator's right to be paid costs out of trust assets is not destroyed by any breach of trust by the trustee.

In its Review of the Law of Trusts: Preferred Approach paper, the Law Commission identified several issues that arise on the insolvency of a company that acted as a trustee. ${ }^{78}$ It made recommendations on some of the issues but left others to an anticipated later review of the area by the Ministry of Business, Innovation and Employment (MBIE). Issues which were identified for later review included whether liquidators are entitled to claim fees and expense from trust assets, whether the priority rules in the Companies Act apply, and the application of the insolvent transaction regime to trust creditors. In its subsequent report, Review of the Law of Trusts: A Trusts Act for New Zealand,

74 Clause 1(1)(a).

75 Clause 1(2)

76 See Lynne Taylor and Grant Slevin The Law of Insolvency in New Zealand (Thomson Reuters, Wellington, 2016) at [24.1]; and Paul Heath and Mike Whale Health and Wale: Insolvency Law in New Zealand (2nd ed, LexisNexis, Wellington, 2014) at [18.1] and [18.8(f)].

77 Re Suco Gold, above n 6, at 883.

78 New Zealand Law Commission Review of the Law of Trusts: Preferred Approach (NZLC IP31, 2012) at ch 8. 
the Commission confirmed its view that more protection is needed to strengthen the position of creditors of a company that acted as trustee. ${ }^{79}$ The report indicated that rather than leaving this matter with MBIE, the Commission will (at some later unspecified date) undertake a "corporate trustee review" where the outstanding issues will be considered. ${ }^{80}$ The issues identified to be dealt with in that review include whether trust assets are available to meet the expenses of a winding up. It is to be hoped that this review will be undertaken in the near future.

\section{CONCLUSION}

The New Zealand courts have recognised three alternative bases on which the liquidator of a trustee of a trading trust can access trust assets to pay the liquidator's costs. This article has suggested that none of the three bases provide a sound conceptual basis for payment from trust assets of the liquidator's general costs of winding up the trustee.

Each of those bases requires a connection between the costs incurred by the liquidator and the carrying on of the trusts. The first basis requires the closest connection, in that the costs must arise from liquidator's actions to preserve or realise the trust assets for the benefit of the beneficiaries. Often the only connection between the liquidator's actions and the carrying out of the trust is that the company in liquidation would otherwise have to pay these debts as part of its role as trustee, and if not paid, the creditors would have a right themselves to subrogate to the trustee's right of indemnification. Whether this forms a sufficient connection to enliven the trustee's indemnity (as was the view taken in Ranolf) is debatable. Liquidator's costs do not seem to be regarded as a debt of the company under the New Zealand Companies Act, potentially closing off the option of using the reasoning in Re Suco Gold that the scheme of that Act authorises payment of costs out of trust assets.

Legislation is desirable to clarify that a liquidator of a company that acted as a trustee is able to exercise the trustee's right of indemnification to pay, from trust assets, its reasonably incurred costs (including remuneration and expenses) that relate to the winding up of the company, to the extent that those costs relate to investigations and realisations of assets for trust creditors.

79 New Zealand Law Commission Review of the Law of Trust: A Trusts Act for New Zealand (NZLC R130, 2013) at [16.8].

80 At [4]. 


\section{SCHEDULE}

New Zealand cases since 2010 that have involved facts where a party was operating a business through a trading trust.

XXX v CIR [2010] NZTRA 13.

Frimley Estate Ltd v Stonewall Homes Ltd HC Napier CIV-2009-441-237, 15 December 2010.

Wiltshire Investments Ltd v Halstead (2010) 19 PRNZ 932 (HC).

Henderson v Commissioner of Inland Revenue HC Auckland CIV-2009-404-4351, 9 June 2011.

Lee v Gao HC Auckland CIV 2010-404-3599, 19 May 2011.

Public Trust as Trustee of the Abrie Trading Trust v Abrie [2012] NZHC 541.

Symons $v$ Wise.Net Trading Trust [2012] NZERA Christchurch 74.

Equinor Trust Ltd v ASB Bank Ltd [2013] NZHC 10.

ISAC New Zealand Ltd v John Managh [2013] NZHC 3242.

$R v$ Gilchrist [2013] NZHC 1868.

Re Tames [2013] NZHC 1089.

Grant and Khov (liquidators of Grastin Investments Ltd (in liq)) v Stinson [2013] NZHC 325.

Ng v Harkness Law Ltd (No 2) [2014] NZHC 1667.

Sardan Trustees Ltd v Magson's Hardware Ltd [2014] NZHC 460.

Pram Enterprises Ltd (in liq) v Mansfield [2016] NZHC 230.

Roose v Duthie [2015] NZHC 2035.

Brainich-Felth-Eilander v Ward [2016] NZHC 2481.

Commissioner of Inland Revenue v Robertson [2017] NZHC 31.

Crummer Trustees No 83 Ltd v Bank of New Zealand [2016] NZHC 1539.

Leeds v Richards (No 2) [2016] NZHC 3039.

Public Trust $v$ Sliverfern Vineyards Ltd [2016] NZHC 1656.

Watson \& Son Ltd $v$ Whitehead [2016] NZCA 241.

LSF Trustees Ltd v Footsteps Trustee Company Ltd (in liq) [2017] NZHC 2619.

Ranolf Co Ltd (in liq) v Bhana [2017] NZHC 1183. 
Shailer v Shailer [2017] NZHC 2871.

Shaw v Owens and Vance (as liquidators of Aluminium Plus Wellington Ltd) [2017] NZCA 315.

Venkataswamy v Kodoor and Ganesh [2017] NZHC 554.

Biggs v Biggs [2018] NZCA 546.

Foote v Progressive Reality Ltd [2018] NZERA Christchurch 60.

NZ Natural Therapy Ltd (in liq) v Little [2018] NZHC 2164.

Camray Farms Ltd (in liq) v BL (Nature Sunshine) Trustee Ltd [2019] NZHC 2536. 
